\title{
CORRESPONDENCE
}

\section{Pyroxene accumulation in spinifex-textured rocks}

SIR - Campbell \& Arndt (1982) have emphasized that in komatiitic lava flows of relatively low $\mathrm{MgO}$ content pyroxene rather than olivine occurs as the dominant elongate mineral in the $A_{2}$ (spinifex) unit, even though equilibrium phase relations indicate that olivine should have crystallized for many tens of degrees before pyroxene crystallization (Arndt, 1976). They attribute this anomaly to extreme supercooling of lava to below the temperature of a postulated olivine $\rightarrow$ pyroxene peritectic at approximately $1200^{\circ} \mathrm{C}$, with subsequent metastable crystallization of pyroxene. As an instance of this behaviour Campbell \& Arndt cite Fred's flow in Munro Township (Arndt, Naldrett \& Pyke, 1977) and show that the lava would have had to be supercooled by approximately $170^{\circ} \mathrm{C}$ to enter the stability field of pyroxene. The flow is $120 \mathrm{~m}$ thick and has a chilled margin containing $16 \% \mathrm{MgO}$ (15\% normative olivine). The pyroxene-spinifex zone begins $7 \mathrm{~m}$ below the top of the flow, where the cooling rate would have been on the order of just $0.01-0.001 \% \mathrm{C} \mathrm{h}^{-1}$ (estimated from Jaeger, 1968, p. 511).

Experiments conducted by Walker et al. (1976), Grove \& Walker (1977) and Donaldson (1979) quantify the effect of cooling rate in the supercooling of mafic and ultramafic magmas with respect to olivine. In order to supercool a melt with $11 \%$ normativeolivineby $170^{\circ} \mathrm{C}$, acoolingrate exceeding $1000{ }^{\circ} \mathrm{C} \mathrm{h}^{-1}$ is necessary (extrapolation of curves in Fig. $3 \mathrm{c}$ of Donaldson, 1979). Hence, although controlled cooling rate experiments on Fred's flow material are needed to test Campbell \& Arndt's proposition, the existing results on other olivine-normative melts do not encourage the view that, during slow cooling $\left(<1^{\circ} \mathrm{C} \mathrm{h}^{-1}\right)$, the magma supercooled by the $170^{\circ} \mathrm{C}$ needed to suppress olivine in favour of metastable pyroxene.

Other evidence against the proposal is the $5-7 \mathrm{~m}$ thick zone of olivine-spinifex between the top of Fred's flow and the pyroxene-spinifex zone (Arndt et al. 1977). Nearer the top of the flow cooling would have been faster than lower down and greater supercooling would have resulted. Yet it is olivine, not pyroxene, that forms under the faster cooling conditions.

While not disagreeing with Campbell \& Arndt that $\mathbf{A}_{2}$ spinifex zones are 'cumulates' in the sense of Irvine (1982), it seems to me that the discrepancy between the phase relations and the actual mineral constitution of Fred's flow is still not adequately explained.

Two promising ideas have emerged since the publication of Campbell \& Arndt's paper. These are: (a) that during solidification of Fred's flow magma flowed continuously under the chilled margin and changed composition (cf. Barnes, Gorton \& Naldrett, 1983), becoming cooler and more fractionated during crystallization of the pyroxenespinifex zone as compared with that from which the overlying zones crystallized; and $(b)$ that komatiite flows cool convectively rather than conductively (Huppert et al. 1984), resulting in much faster cooling than previously appreciated, and possibly fast enough to enter the pyroxene metastable field.

\section{References}

ARndT, N. T. (1976). Melting relationships of ultramafic lavas (komatiites) at one atmosphere and high pressure. Carnegie Institution of Washington Yearbook 75 , 555-61.

ARndt, N. T., Naldrett, A. J. \& Pyke, D. R. 1977. Komatiitic and iron-rich tholeiitic lavas of Munro Township, northeast Ontario. Journal of Petrology 18, 319-69.

Barnes, S. J., Gorton, M. P. \& Naldrett, A. J. 1983. A comparative study of olivine and clinopyroxene spinifex flows from Alexo, Abitibi Greenstone Belt, Ontario, Canada. Contributions to Mineralogy and Petrology 83, 293-308.

Campbell, I. H. \& Arndt, N. T. 1982. Pyroxene accumulation in spinifex-textured rocks. Geological Magazine $119,605-10$

Donaldson, C. H. 1979. An experimental investigation of the delay in nucleation of olivine in mafic magmas. Contributions to Mineralogy and Petrology 69, 21-32.

Grove, T. L. \& Walker, D. 1977. Cooling histories of Apollo 15 quartz-normative basalts. Proceedings of the 8th Lunar Science Conference 1501-20.

Huppert, H. E., SPARKs, R. S. J., TuRner, J. S. \& ARndt, N. T. 1984. The emplacement and cooling of komatiite flows. Nature 309, 19-22.

IRVINE, N. 1982. Terminology for layered intrusions. Journal of Petrology 23, 127-62.

JAEGER, J. C. 1968. Cooling and solidification of igneous rocks. In Basalts, vol. 2 (eds. H. H. Hess and A. Poldervaart), pp. 503-36. New York: Interscience Publishers.

WALKer, D., KirkPATRICK, R. J., LONGHI, J. and HAYS, J. F. 1976. Crystallization history of lunar picritic basalt sample 12002: phase equilibria and cooling rate studies. Bulletin of the Geological Society of America 87, 646-56.

\section{H. DONALDSON}

Department of Geology

University of St Andrews,

St. Andrews, Fife KY16 9ST

4th January 1984 